\title{
KETAHANAN DAN KEMANDIRIAN PANGAN RUMAH TANGGA TANI DAERAH MARGINAL DI KABUPATEN BOJONEGORO
}

\author{
Households' Food Security and Food Self Sufficiency in the Rural Marginal Area \\ of Bojonegoro Regency
}

\author{
Jangkung Handoyo Mulyo ${ }^{1,2}$, Sugiyarto ${ }^{1}$, Arif Wahyu Widada ${ }^{1}$ \\ ${ }^{1}$ Jurusan Sosial Ekonomi Pertanian, Fakultas Pertanian, Universitas Gadjah Mada \\ ${ }^{2}$ Pusat Studi Kependudukan dan Kebijakan, Universitas Gadjah Mada
}

\begin{abstract}
Food security and food self-sufficiency at household level are much determined by their farm production. Meanwhile, some areas considered as the marginal area are constrained by limited support of natural resources. Thus, many households lived in marginal area will face food insecurity. This study aimed to understand the households' food security level, both measured by using the Energy Sufficiency Score (AKE) and the Food Expenditure Share (PPP). Furthermore, this study also tries to identify the food self-sufficiency level among rural marginal household in Bojonegoro Regency. The result of study shows that there is a wide disparity among rural household in the food/energy intake, this is shown by the average level of food/energy intake level that is considered high (87\%), meanwhile there is $53 \%$ of the households categorized as the food insecure household. Based on the Food Expenditure Share level, most of the households are categorized as food secure households. The food self-sufficiency, particularly rice, have been attained.
\end{abstract}

\section{Keywords: Food security, self-sufficiency, marginal area, rural households}

\section{INTISARI}

Ketahanan dan kemandirian pangan bagi suatu rumah tangga tani tentu sangat dipengaruhi oleh produksi pangan dari usahataninya. Kegiatan usahatani tentu tidak akan maksimal bila lahan yang diusahakan termasuk ke dalam daerah marginal. Keadaan ini diduga akan berdampak pada keadaan ketahanan dan kemandirian pangan rumah tangga tani yang hidup di daerah marginal di Kabupaten Bojonegoro, Jawa Timur. Penelitian ini bertujuan untuk 1) mengetahui ketahanan pangan rumah tangga tani menggunakan pendekatan AKE, 2) mengetahui ketahanan pangan rumah tangga tani menggunakan pendekatan PPP, 3) mengetahui keragaan ketahanan pangan, dan 4) mengetahui keadaan kemandirian pangan rumah tangga tani daerah marginal di Kabupaten Bojonegoro. Penelitian dilaksanakan di Kabupaten Bojonegoro, Jawa Timur dengan sampel rumah tangga tani yang hidup atau melakukan kegiatan usahatani di daerah marginal. Metode analisis yang digunakan untuk menjawab tujuan penelitian adalah persamaan AKE, PPP, dan KP, serta analisis tabel untuk menunjukkan keragaan ketahanan pangan. Hasil dari penelitian ini menunjukkan distribusi rumah tangga tani menurut AKE lebih banyak yang belum tahan pangan (53\%) tetapi reratanya sudah tahan pangan (87\%) berarti terdapat disparitas kecukupan energi antar rumah tangga tani. Rumah tangga tani termasuk sudah tahan pangan pada kategori PPP rendah (44\%) dengan distribusi sebesar $87 \%$. Keragaan ketahanan pangan terbesar rumah tangga tani adalah pada kategori kurang pangan dan tahan pangan. Rumah tangga tani daerah marginal di Kabupaten Bojonegoro sudah mandiri pangan untuk kebutuhan makanan pokok berupa beras dengan asumsi panen digunakan untuk mencukupi kebutuhan pangan.

Kata kunci: AKE, PPP, ketahanan pangan, kemandirian pangan, daerah marginal, rumah tangga tani.

\section{PENDAHULUAN}

Sektor pertanian memiliki peran yang sangat strategis dalam sebuah negara. Hal ini karena dari sektor pertanianlah kebutuhan paling pokok manusia dapat dipenuhi. Berdasarkan Rancangan UndangUndang tentang Pangan yang telah disahkan melalui sidang pleno Dewan Perwakilan Rakyat Republik Indonesia pada tanggal 18 Oktober 2012, pangan adalah segala sesuatu yang berasal dari sumber hayati produk pertanian, perkebunan, kehutanan, perikanan, peternakan, perairan, dan air, baik yang diolah maupun tidak diolah yang diperuntukkan sebagai makanan atau minuman bagi konsumsi manusia, termasuk bahan tambahan Pangan, bahan baku Pangan, dan bahan lainnya yang digunakan dalam proses penyiapan, pengolahan, dan/atau pembuatan makanan atau minuman.

Bojonegoro merupakan daerah penghasil padi yang dalam mengusahakannya sangat 
dipengaruhi oleh faktor alam seperti lahan marginal yang disebabkan salah satunya daerah banjir. Berdasarkan penelitian yang dilakukan oleh Supardi et al., (2012) tentang pemetaan kerawanan pangan di Kabupaten Bojonegoro, yaitu pemetaan kondisi kerawanan pangan di tingkat wilayah/ daerah rawan banjir menunjukkan bahwa dari 28 kecamatan di Kabupaten Bojonegoro hanya sebanyak 9 kecamatan yang berwarna kuning, sedangkan 19 kecamatan lainnya berwarna hijau. Kerawanan pangan akan mengancam ketahanan pangan masyarakat. Purwantini et al. (2000) meneliti ketahanan pangan nasional menggunakan pendekatan kecukupan energi (Kkal). Ilham dan Sinaga (2007) dengan topik yang sama meneliti ketahanan pangan menggunakan pendekatan pangsa pengeluaran pangan sebagai indikator karena dapat diukur dengan angka, cukup sederhana untuk memperoleh dan menafsirkannya, objektif,dan responsif terhadap perubahan-perubahan akibat adanya perubahan kondisi perekonomian, kebijakan dan program pembangunan. Rachman etal.(2005) mengukur derajat ketahanan pangan dengan indikator Jonsson and Toole (1991 dalam Maxwell, D., etall., 2000) dengan mengombinasikan AKE dan PPP yang dibagi dalam empat kuadran.Faktor lingkungan dalam hal ini lahan (Mulyo et al., 2010) juga dapat mempengaruhi status ketahanan pangan petani sebagai penghasil pangan sehingga selain menunjukkan status ketahanan pangan juga dapat menunjukkan status kemandirian pangan mereka (Adekoya, 2009).

\section{METODE PENELITIAN}

Metode dasar yang digunakan merupakan metode penelitian deskriptif. Metode deskriptif adalah suatu metode penelitian yang dilaksanakan untuk meneliti status kelompok manusia, suatu obyek, suatu kondisi, suatu sistem pemikiran atau suatu peristiwa pada saat sekarang (Nasir, 2011).

Data yang digunakan dalam penelitian ini adalah sebagian data dari penelitian Analisis Pola Pangan Harapan Kabupaten Bojonegoro yang dilakukan di 28 kecamatan di Kabupaten Bojonegoro yang diketuai oleh Jangkung Handoyo Mulyoc di tahun 2014. Sampel dari penelitian ini adalah rumah tangga tani yang berada pada daerah marginal di Kabupaten Bojonegoro yaitu di daerah tambang, pinggiran hutan, dan pinggir bengawan. Daerah ini merupakan daerah marginal di Kabupaten Bojonegoro karena merupakan lahan kering dan rawan banjir untuk pengembangan usahatani.

Metode analisis data untuk tujuan pertama yaitu mengukur tingkat ketahanan pangan rumah tangga tani menggunakan pendekatan Angka Kecukupan Energi (AKE) digunakan perhitungan dengan pengukuran yang sudah ada. Pengukuran tingkat kecukupan energi mengikuti persamaan Purwantini et. al, (2005):

1. Konsumsi Energi Ekuivalen Orang Dewasa

$$
\mathrm{KED}=\mathrm{KErt} / \mathrm{JUED}
$$

Keterangan :

KED $=$ konsumsi energi per ekuivalen orang dewasa

KErt $=$ konsumsi energi riil rumah tangga

JUED $=$ jumlah unit ekuivalen dewasa (setara dengan banyaknya anggota rumah tangga)

2. Persentase Kecukupan Energi

$$
\mathrm{PKE}=\mathrm{KED} / 2150 \times 100 \%
$$

Keterangan:

$\mathrm{PKE}=$ persentase kecukupan energi (\%)

KED $=$ konsumsienergi dan protein per ekuivalen orang dewasa

Angka tetapan energi adalah sebesar $2.150 \mathrm{kkal} /$ kapita/hari (Permenkes No. 75 tahun 2013)

Suatu rumah tangga tani dikatakan tahan pangan bila nilai PKE lebih besar atau sama dengan dari $80 \%$. Sebaliknya, bila nilai PKE kurang dari $80 \%$ maka rumah tangga tani termasuk dalam golongan belum tahan pangan.

Untuk menjawab tujuan kedua yaitu mengukur tingkat ketahanan pangan rumah tangga tani menggunakan pendekatan Pangsa Pengeluaran Pangan (PPP) digunakan suatu persamaan seperti yang disampaikan oleh Ilham dan Sinaga (2007) sebagai berikut:

$$
\mathrm{PPP}=\frac{F E}{T E} \times 100 \%
$$

Keterangan :

$\mathrm{PPP}=$ pangsa pengeluaran pangan $(\%)$

$\mathrm{FE}=$ pengeluaran untuk belanja pangan (Rp/tahun)

$\mathrm{TE}=$ total pengeluaran rumah tangga $(\mathrm{Rp} /$ tahun) 


\begin{tabular}{lclc}
\hline & \multirow{2}{*}{$\begin{array}{c}\text { Konsumsi Energi per Unit } \\
\text { No. }\end{array}$} & \multicolumn{2}{c}{ Pangsa Pengeluaran Pangan } \\
\cline { 3 - 4 } & & Rendah $(<60 \%$ pengeluaran total $)$ & $\begin{array}{c}\text { Tinggi }(\geq 60 \% \\
\text { pengeluaran Total })\end{array}$ \\
\hline 1. & Cukup $(>80 \%$ Kecukupan Energi) & Tahan Pangan & Rentan Pangan \\
2. & Kurang $(\leq 80 \%$ Kecukupan Energi) & Kurang Pangan & Rawan Pangan \\
\hline
\end{tabular}

Sumber : Johnsson and Toole, 1991 dalam Maxwel dan Frankenberger, 1992.

Suatu rumah tangga tani dikatakan tahan pangan bila nilai PPP lebih kecil dari $60 \%$. Sebaliknya, bila nilai PPP lebih dari atau sama dengan $60 \%$ maka rumah tangga tani termasuk dalam golongan belum tahan pangan.

Untuk menjawab tujuan ketiga yaitu keragaan ketahanan pangan rumah tangga tani digunakan kriteria keragaan ketahanan pangan oleh Johnsson and Toole dalam Maxwel dan Frankenberger (1992) dengan menggabungkan antara kriteria ketahanan pangan menggunakan AKE dan PPP dan disajikan ke dalam 4 kuadran.

Dari tabel diatas dapat diketahui distribusi keragaan ketahanan pangan rumah tangga tani daerah marginal di Kabupaten Bojonegoro. Keragaman ketahanan pangan akan tersaji ke dalam kelompok tahan pangan, rentan pangan, kurang pangan, dan rawan pangan dalam bentuk persentase.

Untuk menjawab tujuan keempat yaitu kemandirian pangan rumah tangga tani daerah marginal di Kabupaten Bojonegoro digunakan persamaan sebagai berikut:

$$
K P(i)=\frac{P S(i)}{T K(i)}
$$

Keterangan :

$\mathrm{KP}(\mathrm{i})=$ Kemandirian pangan pangan untuk komoditas $i$

PS (i) $=$ Produksi sendiri untuk komoditas $i$ $(\mathrm{Kg})$

TK (i) $=$ Total konsumsi rumah tangga untuk komoditas $i(\mathrm{Kg})$

Suatu rumah tangga tani akan mencapai kemandirian pangan bila apa yang dikonsumsi dapat terpenuhi dari produksi sendiri yang ditunjukkan dengan nilai KP(i) sama dengan 1. Semakin besar nilai KP maka keadaan rumah tangga tani akan semakin mandiri dalam hal pangan. Semakin kecil nilai KP (kurang dari 1), maka rumah tangga tani tersebut berada pada keadaan kurang pangan.

\section{HASIL DAN PEMBAHASAN}

\section{Ketahanan Pangan Rumah Tangga Tani berdasarkan Angka Kecukupan Energi(AKE)}

Angka Kecukupan Energi (AKE) merupakan nilai yang menunjukkan serapan energi individu dari makanan yang dikonsumsi. AKE ini diukur dalam satuan kilo kalori per kapita per hari. AKE yang dihasilkan dari pengukuran energi konsumsi per kapita rumah tangga daerah marginal di Kabupaten Bojonegoro dapat mencerminkan status ketahanan pangan. Suatu individu dapat dikatakan tahan pangan bila konsumsi telah memenuhi kebutuhan energi setidaknya sebesar $80 \%$ dari angka tetapan serapan energi sebesar $2.150 \mathrm{kkal} /$ kap/hari (Permenkes No. 75 Tahun 2013). Berikut disajikan hasil analisis distribusi rumah tangga tani berdasarkan serapan energi pada tabel 1 .

Tabel 1 Distribusi Rumah Tangga Tani berdasarkan AKE

\begin{tabular}{clc}
\hline No. & Kategori Angka Kecukupan Energi & $\begin{array}{c}\text { Persentase } \\
(\%)\end{array}$ \\
\hline 1. & Kurang ( $\leq 80 \%$ kecukupan energi) & 53 \\
2. & Cukup ( $>80 \%$ kecukupan energi) & 47 \\
\hline & Total & 100 \\
\hline
\end{tabular}

Sumber: Analisis Data Primer, 2015

Tabel 1 menunjukkan bahwa distribusi rumah tangga tani daerah marjinal di Kabupaten Bojonegoro masih lebih banyak yang di bawah $80 \%$ dari tetapan AKE $2.150 \mathrm{kkal} / \mathrm{kap} / \mathrm{hari}$. Hal ini memberitahukan bahwa terdapat $53 \%$ penduduk dari golongan rumah tangga tani yang serapan energinya masih kurang yang berarti belum tahan pangan, sedangkan sisanya sebanyak $47 \%$ masuk dalam kategori cukup yang berarti telah tahan pangan dari aspek serapan energinya. Menurut distribusi memang masih lebih banyak rumah tangga tani yang serapan energinya masih di bawah $80 \%$ dari ketentuan AKE, tetapi perlu dilihat juga rerata serapan energi dari seluruh rumah tangga 
tani daerah marjinal di Kabupaten Bojonegoro. Bila rerata serapan energi berada di atas $80 \%$ dari serapan AKE, maka disparitas serapan energi antar rumah tangga tani daerah marginal cukup tinggi.

Tabel 2 Distribusi AKE dan Makanan yang Dikonsumsi

\begin{tabular}{|c|c|c|c|}
\hline No. & Kelompok pangan & $\begin{array}{l}\text { Serapan } \\
\text { Energi } \\
(\mathrm{Kkal})\end{array}$ & $\begin{array}{c}\text { Angka } \\
\text { Kecukupan } \\
\text { Energi (\%) }\end{array}$ \\
\hline 1. & Padi & 1155,8 & 53,8 \\
\hline 2. & Aneka umbi & 101,1 & 4,7 \\
\hline 3. & Pangan Hewani & 217,9 & 10,1 \\
\hline 4. & Minyak dan Lemak & 64,7 & 3,0 \\
\hline 5. & Buah/Biji Berminyak & 19,3 & 0,9 \\
\hline 6. & Aneka kacang & 173,9 & 8,1 \\
\hline 7. & Gula & 31,7 & 1.5 \\
\hline 8. & Sayur dan Buah & 73,7 & 3,4 \\
\hline \multirow[t]{2}{*}{9.} & Lain-lain & 38,7 & 1,8 \\
\hline & Total & 1876,8 & 87,3 \\
\hline
\end{tabular}

Sumber: Analisis Data Primer, 2015

Rerata serapan energi rumah tangga tani daerah marginal di Kabupaten Bojonegoro sudah lebih tinggi dari tetapan $(80 \%$ dari $2.150 \mathrm{kkal} /$ kap/hari). Hal ini memberitahukan bahwa secara rerata rumah tangga tani daerah marginal di Kabupaten Bojonegoro termasuk ke dalam kategori tahan pangan. Padi memiliki andil terbesar yaitu menyumbangkan 53,8\% dari total AKE. Pangan hewani yang didapatkan kebanyakan dari telur dan ayam menyumbangkan $10 \%$ dari total AKE. Kontribusi ketiga disumbangkan oleh aneka kacang yang kebanyakan berasal dari konsumsi tempe yaitu sebesar $8,1 \%$ dari total AKE. Kebanyakan kebutuhan pangan rumah tangga tani telah bisa dicukupi oleh produksi usahatani terutama beras sebagai makanan pokok dan penyumbang energi terbesar dalam konsumsi sehari-hari.

\section{Ketahanan Pangan Rumah Tangga Tani berdasarkan Pangsa Pengeluaran Pangan (PPP)}

Pangsa Pengeluaran Pangan adalah perbandingan antara pengeluaran tunai untuk membeli pangan rumah tangga dengan pengeluaran rumah tangga total yang terdiri dari pengeluaran pangan dan pengeluaran non pangan. Pangsa pengeluaran pangan dengan tingkat ketahanan pangan memiliki hubungan yang berbanding terbalik yang artinya semakin besar pengeluaran pangan suatu rumah tangga, maka ketahanan pangan rumah tangga tersebut semakin rendah, dan sebaliknya semakin kecil pengeluaran pangan suatu rumah tangga maka ketahanan pangan rumah tangga tersebut semakin tinggi.

Tabel 3 Distribusi Rumah Tangga Tani Berdasarkan Pangsa Pengeluaran Pangan (PPP)

\begin{tabular}{clc}
\hline No. & $\begin{array}{c}\text { Kategori Pangsa Pengeluaran } \\
\text { Pangan }\end{array}$ & $\begin{array}{c}\text { Persentase } \\
(\%)\end{array}$ \\
\hline 1. & Rendah $(<60 \%$ pengeluaran total $)$ & 87 \\
2. & Tinggi $(\geq 60 \%$ pengeluaran total $)$ & 13 \\
\hline & Total & 100 \\
\hline
\end{tabular}

Sumber: Analisis Data Primer, 2015

Rumah tangga tani daerah marginal di Kabupaten Bojonegoro memiliki pangsa pengeluaran pangan yang rendah, artinya pengalokasian pengeluaran untuk mencukupi kebutuhan pangan lebih rendah dibandingkan dengan pengalokasian pengeluaran untuk mencukupi kebutuhan non pangan. Tabel 3 menunjukkan bahwa berdasarkan PPP rumah tangga tani termasuk ke dalam kategori tahan pangan.

Petani yang hidup di daerah marginal berjuang untuk bisa berusahatani dengan berbagai intensifikasi untuk mendapatkan panen yang baik. Panen yang didapatkan tidak semuanya dimanfaatkan untuk mencukupi kebutuhan pangan, tetapi juga dijual untuk mencukupi kebutuhan non pangan.

Tabel 4. Rerata Pengeluaran Pangan Rumah Tangga Tani Daerah Marginal di Kabupaten Bojonegoro Tahun 2014.

\begin{tabular}{llrr}
\hline No. & Jenis Pengeluaran & Nilai (Rp) & $\begin{array}{r}\text { Persentase } \\
(\%)\end{array}$ \\
\hline 1. & Beras & 2.625 .475 & 18,46 \\
2. & Lain-lain (camilan) & 1.932 .000 & 13,59 \\
3. & Lauk-pauk & 3.666 .597 & 25,78 \\
4. & Sayur dan Bumbu & 2.103 .207 & 14,79 \\
5. & Minyak Goreng & 1.013 .864 & 7,13 \\
6. & Minuman & 894.847 & 6,29 \\
7 & Rokok & 1.983 .932 & 13,95 \\
\hline & Total & 14.219 .922 & 100,00 \\
\hline
\end{tabular}

Sumber: Analisis Data Primer, 2015.

Tabel 4 menunjukkan bahwa pengeluaran pangan rumah tangga tani terbesar digunakan untuk membeli lauk-pauk dengan persentase sebesar $25,78 \%$. Hampir seluruh lauk pauk yang 
dikonsumsi didapatkan dengan cara membeli, baik membeli bahan mentah atau bahan jadi siap konsumsi. Lauk pauk adalah pendamping wajib nasi selain sayuran, sehingga kehadiran lauk pauk selalu diusahakan untuk ada di atas meja.

Pengeluaran terbesar kedua adalah beras yaitu sebesar 18,46\%. Responden adalah petani padi, tetapi juga membeli beras untuk kebutuhan pangan mereka. Hal ini disebabkan karena panen juga dijual untuk mendapatkan uang yang digunakan untuk memenuhi kebutuhan pagan maupun non pangan. Lebih menjadi perhatian adalah tidak sedikit dari petani di daerah marginal yaitu sebesar $12 \%$ petani yang menjual panennya dengan cara tebasan. Penjualan dengan sistem tebasan berarti petani menjual semua panen tanpa menyisihkan untuk kebutuhan pangan sendiri. Hal ini tidak hanya terjadi pada padi, tetapi juga pada komoditas pangan lain yaitu jagung dan umbi-umbian.

Pengeluaran pangan terbesar ketiga adalah sayur dan bumbu sebesar $14,79 \%$. Sayur adalah pangan pelengkap selain lauk pauk yang penting keberadaannya di atas meja. Sayur kebanyakan didapatkan dengan cara membeli. Kondisi lahan pertanian di daerah marginal yang kebanyakan adalah tanah kering dan tadah hujan tidak memungkinkan petani untuk mengusahakan sayuran. Bumbu merupakan bahan perasa yang penting untuk menambahkan cita rasa pada makanan baik lauk pauk maupun sayur. Bahan ini juga hampir 100\% didapatkan dengan cara membeli.

Pengeluaran yang cukup mencengangkan ternyata adalah rokok yang menempati urutan keempat yaitu sebesar 13,95\% setelah makanan pokok lauk pauk, beras, serta sayur dan bumbu. Rokok sebagian besar hanya dinikmati oleh kepala rumah tangga dan hanya memberikan sensasi, tidak menyumbangkan nutrisi atau nilai gizi pada kebutuhan pangan. Pengalokasian pengeluaran untuk rokok tentunya menjadi perhatian, di saat pemenuhan serapan energi masih di bawah 2.150 $\mathrm{kkal} / \mathrm{kap} /$ hari. Pengeluaran untuk rokok sebaiknya bisa dialokasikan untuk meningkatkan pemenuhan kualitas lauk pauk, sayur, serta bahan pangan pelengkap lainnya untuk mencapai serapan energi dan nilai gizi yang baik bagi keluarga.

Pengeluaran non pangan terbesar masih dialokasikan untuk membeli BBM. Hal ini membuktikan bahwa kebutuhan masyarakat untuk energi masih sangat besar, terutama untuk
Tabel 5. Rerata Pengeluaran Non Pangan Rumah Tangga Tani Daerah Marginal di Kabupaten Bojonegoro Tahun 2014.

\begin{tabular}{clrr}
\hline No. & Jenis Pengeluaran & Nilai (Rp) & $\begin{array}{r}\text { Persentase } \\
(\%)\end{array}$ \\
\hline 1. & Pakaian & 856.333 & 6,33 \\
2. & Kesehatan & 833.000 & 6,15 \\
3. & MCK (sabun mandi, & 963.700 & \\
& pasta gigi, dll) & & 7,12 \\
4. & Kegiatan Sosial & 2.066 .833 & 15,27 \\
5. & BBM & 3.882 .133 & 28,68 \\
6. & Listrik & 849.000 & 6,27 \\
7. & Gas & 710.700 & 5,25 \\
8. & Pendidikan & 2.656 .833 & 19,63 \\
9. & PBB & 113.933 & 0,84 \\
10. & Pajak Kendaraan & 605.333 & 4,47 \\
\hline & Total & 13.537 .800 & 100,00 \\
\hline
\end{tabular}

Sumber: Analisis Data Primer, 2015

kebutuhan mobilitas anggota rumah tangga tani. Rumah tangga tani mengeluarkan banyak uang untuk BBM dikarenakan beberapa anggota keluarga hilir mudik menuju kota untuk melakukan kegiatan luar usahatani, misalnya berdagang, bekerja, dan sekolah. Biasanya mereka menggunakan kendaraan sepeda motor tetapi ada juga anggota rumah tangga yang menggunakan mobil, jarak yang harus ditempuh dari rumah menuju tempat tujuan menggunakan kendaraan bermotor ini membuat anggota rumah tangga tani harus mengisi bahan bakar agar kendaraan mereka bisa digunakan. Semakin jauh tempat mereka bekerja atau sekolah maka bahan bakar yang diperlukan untuk mengisi kendaraan mereka juga semakin sering dibeli. Pengeluaran terbesar kedua adalah pendidikan. Walaupun rumah tangga tani hidup di daerah marginal, tetapi perhatian mereka untuk mencapai pendidikan yang tinggi masih sangat diperjuangkan. Hal ini terbukti dengan banyaknya anggota rumah tangga yang memiliki pendidikan yang tinggi hingga perguruan tinggi. Selanjutnya, pengeluaran non pangan yang besar adalah untuk kegiatan sosial. Hal ini menunjukkan bahwa rumah tangga tani juga mengeluarkan uang yang cukup banyak untuk kegiatan sosial, misalnya hajatan pernikahan, sumbangan apabila ada yang meninggal atau melahirkan, khitanan, dan lain-lain. Jika yang memiliki hajatan adalah kerabat dekat maka uang yang dikeluarkan untuk kegiatan sosial menjadi lebih banyak disamping memberikan uang, biasanya mereka juga menyumbang gula, kopi, teh, mi instan, minyak goreng, ataupun makanan. 
Tabel 6 Rerata Persentase Pengeluaran Rumah Tangga Tani

\begin{tabular}{clc}
\hline No. & Kategori Pengeluaran & Persentase (\%) \\
\hline 1. & Pangan & 44 \\
2. & Non Pangan & 56 \\
\hline & Total & 100 \\
\hline
\end{tabular}

Sumber: Analisis Data Primer, 2015

Tabel 6 menunjukkan rangkuman dari rerata pengeluaran pangan dan non pangan rumah tangga tani daerah marginal di kabupaten Bojonegoro. Dari tabel tersebut dapat diketahui bahwa secara umum pengeluaran rumah tangga tani untuk non pangan lebih besar dari pada pangan, dan pengeluaran pangan kurang dari $60 \%$. Rumah tangga tani berdasarkan perhitungan ini tergolong ke dalam tahan pangan menurut perhitungan menggunakan Pangsa Pengeluaran Pangan (PPP).

\section{Keragaan Ketahanan Pangan Rumah Tangga Tani}

Kombinasi silang antara pangsa pengeluaran pangan dan angka kecukupan energi digunakan untuk mengetahui tingkat ketahanan pangan rumah tangga. Tingkat ketahanan pangan tersebut dibagi menjadi empat kategori, yaitu tahan pangan, rentan pangan, kurang pangan, dan rawan pangan. Hasil dari kombinasi silang antara pangsa pengeluaran pangan dan angka kecukupan energi diperoleh jumlah rumah tangga tani pada masing-masing kategori tingkat ketahanan pangan dan dinyatakan dalam persentase.

Sebagian besar distribusi rumah tangga tani berada pada kategori tahan pangan dan kurang pangan. Hal ini berarti sebagian besar rumah tangga tani memiliki pangsa pengeluaran pangan yang rendah dan terdistribusi pada golongan yang sudah cukup serapan energinya dan yang belum. Pangsa pengeluaran pangan yang rendah berarti rumah tangga tani sudah dapat mencukupi kebutuhan pangan mereka dengan baik dan mulai mengalokasikan pengeluaran mereka untuk mencukupi kebutuhan berbagai kebutuhan non pangan. Dari tabel 5 dapat diketahui bahwa edukasi dalam mengkonsumsi berbagai macam pangan yang berkualitas menjadi perhatian agar serapan energi rumah tangga semakin tercukupi sehingga rumah tangga yang masuk ke dalam golongan rawan pangan dapat bergeser ke dalam kategori tahan pangan.

Petani adalah produsen pangan. Tentu pangan yang diproduksi tidak sebanyak yang bisa diproduksi di lahan yang subur dengan pengairan yang baik. Rata-rata petani hanya bisa menanam padi satu hingga paling banyak dua kali dalam setahun. Pada musim tanam ke dua ada yang masih ditanami padi, ada pula yang ditanami palawija. Pada musim tanam ketiga banyak yang ditanami palawija tetapi tidak sedikit yang dibiarkan kosong karena keterbatasan air. Kemandirian pangan dapat diketahui dari seberapa besar kebutuhan pangan rumah tangga tani dapat dicukupi dari produksi pangan mereka sendiri. Khusus untuk padi sebagai makanan pokok, petani daerah marginal di Kabupaten Bojonegoro sudah surplus dengan asumsi panenan mereka hanya digunakan untuk mencukupi kebutuhan pangan saja, baru sisanya dijual untuk mencukupi kebutuhan lain.

\section{Kemandirian Pangan Rumah Tangga Tani}

Dalam mencukupi kebutuhan pangan, setiap rumah tangga akan berusaha mencukupinya melalui berbagai cara, baik mengusahakan sendiri melalui produksi tanaman pangan atau membeli bahan pangan dengan sejumlah uang yang senilai. Petani adalah produsen pangan yang dalam kehidupannya juga memerlukan pangan. Bila petani dapat mencukupi kebutuhan pangan mereka sendiri berarti rumah tangga tani tersebut sudah tahan pangan, begitu pula sebaliknya.

Tabel 7. Keragaan Tingkat Ketahanan Pangan Rumah Tangga Tani Daerah Marginal di Kabupaten Bojonegoro

\begin{tabular}{llcc}
\hline \multirow{2}{*}{\begin{tabular}{l} 
No. $\begin{array}{l}\text { Konsumsi Energi per Unit } \\
\text { Ekuivalen Dewasa }\end{array}$ \\
\cline { 3 - 4 }
\end{tabular}} & $\begin{array}{c}\text { Rendah }(<60 \% \\
\text { pengeluaran total) }\end{array}$ & $\begin{array}{c}\text { Tinggi }(\geq 60 \% \text { pengeluaran } \\
\text { Total) }\end{array}$ \\
\hline 1. Cukup ( $>80 \%$ Kecukupan Energi) & $\begin{array}{c}40.00 \% \\
\text { (Tahan Pangan) } \\
46.67 \%\end{array}$ & $\begin{array}{c}6.67 \% \\
\text { (Rentan Pangan) } \\
6.67 \%\end{array}$ \\
2. Kurang ( $\leq 80 \%$ Kecukupan Energi) & (Kurang Pangan) & (Rawan Pangan) \\
\hline
\end{tabular}

Sumber: Analisis Data Primer, 2015 
Tabel 8 Rerata Konsumsi dan Produksi Padi tiap Rumah Tangga Tani Tiap Tahun

\begin{tabular}{clc}
\hline No. & Jenis Kegiatan & Banyak $(\mathrm{Kg})$ \\
\hline 1. & Konsumsi & 441,54 \\
2. & Produksi & $1.563,20$ \\
\hline & Sisa & $1.121,66$ \\
\hline
\end{tabular}

Sumber: Analisis Data Primer, 2015

Dari tabel 6 dapat diketahui bahwa rumah tangga tani masih mengalami surplus untuk kebutuhan konsumsi beras selama setahun dari produksi mereka sendiri. Tentu hasil perhitungan ini diasumsikan panen diutamakan untuk kebutuhan konsumsi pangan, baru sisanya dijual untuk kebutuhan pangan. Kenyataannya petani masih banyak yang membeli beras untuk mengkonsumsi nasi. Hal ini disebabkan hasil panen banyak yang dijual dengan sistem tebasan yaitu sebesar $12 \%$ petani yang melakukan penjualan dengan cara ini. Penjualan dengan cara tebasan tidak akan menyisakan hasil panen untuk memenuhi kebutuhan pangan rumah tangga tani dalam kasus ini adalah beras. Dikarenakan oleh berbagai keterbatasan, anggota rumah tangga tani memiliki beragam pekerjaan lainnya yaitu sebagai wiraswasta, karyawan, bahkan buruh tani. Kemandirian pangan menjadi sangat rawan saat produksi tidak mencukupi untuk kebutuhan rumah tangga tani sehingga harus dikorbankan dalam jumlah besar untuk mencukupi kebutuhan pangan lain seperti lauk pauk dan sayur, serta kebutuhan non pangan yang lebih besar dalam pengalokasian pengeluaran rumah tangga tani.

\section{KESIMPULAN}

Kesimpulan dari penelitian ini adalah rumah tangga tani menurut distribusi AKE masih banyak yang belum cukup serapan energinya, sedangkan menurut rerata serapan energi rumah tangga tani termasuk tahan pangan. Rumah tangga tani menurut PPP tergolong dalam kategori tahan pangan. Kebanyakan rumah tangga tani masuk ke dalam kategori tahan pangan (40\%) dan rawan pangan (47\%).Rumah tangga tani sudah mandiri pangan bahkan bisa dikatakan surplus dari perbandingan produksi dan konsumsi beras selama setahun dengan asumsi panen beras digunakan untuk kebutuhan pangan. Rerata konsumsi beras selama setahun adalah $441,54 \mathrm{~kg}$ sedangkan produksi beras adalah sebesar 1.563,20 kg sehingga terdapat surplus sebesar 1.121,66 kg.
Edukasi tentang mengkonsumsi makanan yang berkualitas akan gizi sangat dibutuhkan agar serapan energi rumah tangga tani dapat meningkat sehingga distribusi rumah tangga tani dapat bergeser dari rawan pangan menjadi tahan pangan. Rumah tangga tani sangat penting melakukan diversifikasi sumber penghidupan selain sebagai petani untuk mencukupi kebutuhan pangan maupun non pangan.

\section{DAFTAR PUSTAKA}

Adekoya, E. Adegbenga. 2009. Food insecurity and coping strategies among rural households in Oyo State, Nigeria. Journal of Food, Agriculture, and Environment 7: 187-191.

Badan Pusat Statistik. 2014. Bojonegoro Dalam Angka. Badan Pusat Statistik Kabupaten Bojonegoro, Bojonegoro.

Ilham, Nyak dan Bonar, M. Sinaga, 2007. Penggunaan Pangsa Pengeluaran Pangan Sebagai Indikator Komposit Ketahanan Pangan. SOCA, Jurnal Sosial Ekonomi Pertanian dan Agribisnis. Fakultas Pertanian Universitas Udayana. Vol. 7 No. 3 : 213-328 November 2007.

Maxwell, S. Dan T.R. Frankenberger. 1992. Household Food Security: Concepts, Indicator, Measurements, A Technical Review. International Fund For Agricultural Development/United Nation Childrens Fund, Rome.

Mulyo, JH., Irham, Widodo dan Sugiyarto. 2009. Kajian Ekonomi Dampak Kenaikan Harga BBM terhadap Ketahanan Pangan Rumah Tangga Tani dan Rumahtangga Industri Rumahtangga Berbasis Produk Pertanian. KKP3T Badan Litbang Pertanian. Jakarta.

Mulyo, JH., Dwidjono, HD., Sugiyarto, Fuad CA. dan B. Riris AW. 2010. Kajian Pengaruh Akses Penguasaan Lahan dan Ketahanan Pangan Rumahtangga Tani di Kabupaten Klaten. Hibah Penelitian Fakultas Pertanian UGM.

Nasir, Moh. 2011. Metode Penelitian. Ghalia Indonesia, Bogor.

Purwantini, Tri Bastuti, Handewi, P. S., dan Yuni Marisa, 2000. Analisis Ketahanan Pangan Regional dan Tingkat Rumah Tangga (Studi Kasus di Provinsi Sulawesi Utara). Pusat Analisis Sosial Ekonomi dan Kebijakan Pertanian. Bogor. 
Rachman, Handewi P.S., Mewa Ariani dan TB Purwantini, 2005. Distribusi Provinsi di Indonesia Menurut Derajat Ketahanan Pangan Rumah Tangga. Pusat Analisis Sosial Ekonomi dan Kebijakan Pertanian. Bogor.
Supardi, S., Erlyna Wida R. dan Aulia Qonita. 2012. Pemetaan kondisi rawan pangan di tingkat wilayah di Kabupaten Bojonegoro. Jurnal Ilmu-ilmu Pertanian 16(2) : 84-90. 